\title{
Current state and changes in Molinion meadows from Kostrze environs in Kraków
}

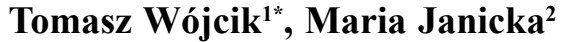 \\ 'Department of Natural Sciences, University of Rzeszów, Cicha 2A, 35-326 Rzeszów, Poland, \\ *e-mail: antomi7@wp.pl \\ ${ }^{2}$ Department of Plant Ecology, Jagiellonian University, Lubicz 46, 31-512 Kraków, Poland
}

\begin{abstract}
The study was carried out in the Kostrze housing estate in Kraków. In the 2015 vegetation season, 35 relevés were taken with the Braun-Blanquet method. The aim of the study was to compile the current characteristics of the vegetation in intermittently wet Molinia meadows and to identify changes that occurred within 25 years. The analysed meadow stands comprised 129 species of vascular plants. The relevés showed the presence of 17-50 species (on average 36). The characteristic species exhibited high abundance and high degrees of constancy. In total, 16 characteristic species of the alliance Molinion were recorded. Molinia caerulea, Galium boreale, and Sanguisorba officinalis were the dominant species in a majority of the analysed stands. The average number of species occurring in the purple moor-grass meadows in Kostrze is currently higher than 25 years ago (an increase from 28 to 36 ). The list of characteristic species has not changed substantially (three new species were noted: Betonica officinalis, Carex tomentosa, and Ophioglossum vulgatum), and the differences in the floristic composition are mainly related to sporadic species. Abandonment of land use triggered succession and a decline in the surface area of the analysed meadows. Therefore, species characteristic for other habitats, primarily tree and shrub seedlings as well as expansive grasses (Calamagrostis epigejos, Phragmites australis) have appeared in these meadow stands.
\end{abstract}

Key words: Molinion caeruleae, changes in meadow communities, succession, burning, abandonment, nature habitats, Sandomierz Basin.

\section{Introduction}

Purple moor-grass meadows from the Molinion caeruleae alliance represent semi-natural communities associated with human activity. Conservation of these meadows in the cultural landscape depends on natural habitat factors (changeable groundwater levels) and sustenance of traditional practices of management. Proper development of Molinia meadows requires late mowing (in late August or early September) at least every second year and lack of fertilisation. Communities from the alliance Molinion have developed on eutrophic, mesotrophic, and oligotrophic substrata in wet and fresh habitats characterised by a variable groundwater level. They occupy muck, muck-gley, and gleysolic soils with alkaline, neutral, or slightly acidic reaction (Ellenberg 1988; Kępczyński \& Załuski 1991; Kucharski 1999; Kołodziejek \& Michalska-Hejduk 2004; Havlová 2006; Řezníčková 2007; Załuski 2007; Trąba \& Wolański 2012).

Molinia meadows represent the most valuable communities in Poland and Europe characterised by high species richness, multi-species structure, specific development phenology, broad ecological amplitude, and presence of many rare and protected species whose occurrence is associated with availability of suitable habitats. Furthermore, purple moor-grass meadows exhibit high regional and local habitat variability as well as exceptional landscape and aesthetic values (Zarzycki 1958; Denisiuk 1987; Kępczyński 
\& Załuski 1991; Pott 1995; Barabasz 1997; Kucharski 1999; Kołodziejek \& Michalska-Hejduk 2004; Kącki 2007; Załuski 2007; Suder 2008; Chytrý 2010; Bochnak 2011; Trąba \& Wolański 2012; Kulik 2013; Somczyk 2013; Hegedüšová \& Škodová 2014).

In Poland, the alliance Molinion has been described to comprise 9 associations and 24 sub-associations as well as many variants (Trąba \& Wolański 2012). The phytocoenotic diversity of purple moor-grass meadows is determined by a number of natural and anthropogenic factors; hence, some of the communities distinguished occupy a limited geographic area. In southwestern Poland, Kącki (2007) distinguished an association Selino carvifoliae-Molinietum consisting of seven sub-associations and an association Galio veri-Molinietum with its three sub-associations. In the Silesian Upland, Suder (2008) described associations Galio borealis-Molinietum and Selino-Molinietum. There are similar reports from other regions of the country (Zarzycki 1958; Kępczyński \& Załuski 1991; Barabasz 1997; Kucharski 1999; Brzeg \& Wojterska 2001; Kołodziejek \& Michalska-Hejduk 2004; Bator 2005; Kompała-Bąba \& Bąba 2007; Somczyk 2013).

Investigations of the communities from the alliance Molinion are also carried out in the neighbouring countries. In Germany, six plant associations have been classified within the alliance Molinion caeruleae: Junco-Molinietum caeruleae, Molinietum caeruleae, Gentiano asclepiadeae-Molinietum, Cirsio tuberosi-Molinietum arundinaceae, Oenantho lachenalii-Molinietum arundinaceae, Galio borealis-Molinietum arundinaceae (Pott 1995). In Slovakia, two associations Junco effusi-Molinietum caeruleae and Molinietum caeruleae have been described, consisting of six sub-associations (Molinietum caricetosum hostianae, Molinietum potentilletosum albae, Molinietum caricetosum paniceae, Molinietosum caricetosum panicae and caricetosum tomentosae, Molinietum deschampsietosum cespitosae, Molinietum caricetosum tomentosae) and one variant (var. Scorzonera humilis) (Řezníčková 2007; Hegedüšová \& Škodová 2014). Two associations have been reported from the Czech Republic: Molinietum caeruleae in three variants (var. Carex hostiana, var. Bromus erectus, and var. Scorzonera humilis) and Junco effusi-Molinietum caeruleae in two variants (var. Valeriana dioica and var. Leucanthemum vulgare) (Havlová 2006; Chytrý 2010).

In recent decades, there have been considerable changes in the management of meadow communities, i.e. intensification or abandonment of land use and changes in water relations. Abandonment of previous management forms leads to changes in the species composition, limitation of species diversity, spread of expansive perennials, and initiation of secondary succession. This process results in loss of species with narrow environmental requirements, floristic impoverishment of stands, an increased proportion of expansive species, and transformation of phytocoenoses towards scrub communities (Tumidajowicz \& Zubel 1978; Ellenberg 1988; Kępczyński \& Załuski 1991; Dubiel 1996; Grynia 1996; Kotańska 1993; Dubiel 1995; Barabasz 1997; Kucharski 1999; Kołodziejek \& Michalska-Hejduk 2004; Bator 2005; Havlová 2006; Kącki 2007; Kompała-Bąba \& Bąba 2007; Řezníčková 2007; Załuski 2007, 2011; Chytrý 2010; Kącki \& Michalska-Hejduk 2010; Bochnak 2011; Kącki 2012; Kulik 2013; Trąba \& Wolański 2012; Hegedüšová \& Škodová 2014). The communities from the alliance Molinion are one of the most endangered in the country. In many regional studies, they are regarded as vulnerable, endangered, and critically endangered phytocoenoses (Kucharski 1999; Brzeg \& Wojterska 2001; Załuski 2007; Kącki \& Michalska-Hejduk 2010).

In order to preserve these unique phytocoenoses, protected areas with extensive forms of management are established (Kołodziejek \& Michalska-Hejduk 2004; Załuski 2007; Kulik 2013). Molinia meadows are on the list of nature habitats included in the Natura 2000 network. The aim of establishment of these sites is to conserve the Molinion caeruleae habitat with its rare species of plants and butterflies (Directive 1992).

The objective of this study was to provide current characterisation of the vegetation of Molinion caeruleae meadows in Kostrze and identify changes that occurred over the last 25 years.

\section{Study area}

The study area is situated in the Vistula River valley, which belongs to the Sandomierz Basin (Kondracki 2011). In terms of the administration division, the complexes of the analysed meadows are located in the Dębniki district in the southwestern part of Kraków. The observations were carried out in an area in the west of the Jagiellonian University Campus delimited by Tyniecka, Winnicka, and Skotnicka Streets (Fig. 1).

Given its location on the border of several different geobotanical units, varied geological structure and relief, and the centuries-old human activity, Kraków is characterised by great flora richness and vegetation diversity. In their analysis of the degree of primary diversity of habitats and plant communities in the city, Kornaś and Medwecka-Kornaś (1974) distinguished six vegetation complexes: riparian forests, oak-hornbeam, thermophilic scrubs, beech, mixed forest, and pine forest. The authors found that changes in the vegetation cover caused by human activity are manifested in the loss of primary plant communities due to destruction thereof, formation of replacement communities, disappearance of native species, and appearance of synanthropic alien species.

The communities of moist and wet meadows have emerged in areas formerly occupied by riparian forests. In 


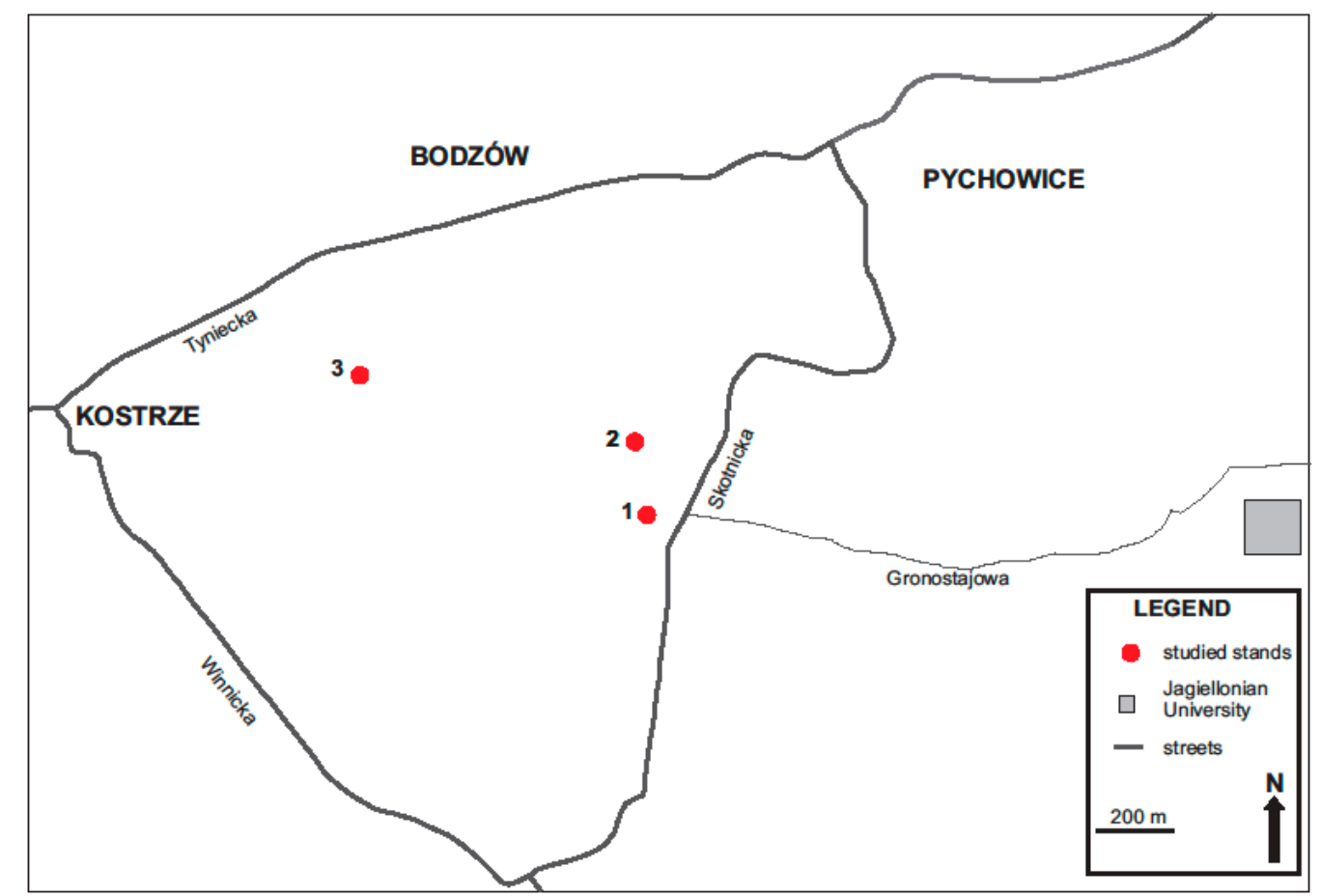

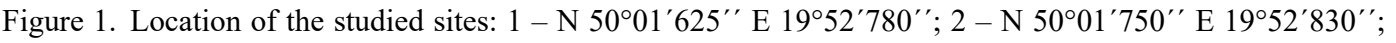
3 - N 5001'800' E $19^{\circ} 52^{\prime} 290^{\prime \prime}$

the early years of the last century, they were often present along the Vistula River valley from Czernichów in the southwest to Niepołomicka Primeval Forest in the northeast of the region. In the second half of the $20^{\text {th }}$ century, they underwent rapid transformation induced by changes in land management and land drainage practices (Zarzycki 1958; Tumidajowicz \& Zubel 1978; Denisiuk 1987; Dubiel 1991, 1995, 1996). An important task was to map the actual vegetation of Kraków that illustrated the rate and scope of changes occurring over subsequent years (Dubiel 1991; Dubiel \& Szwagrzyk 2008). The authors of these studies repeatedly emphasised the most valuable nature areas that should be excluded from development plans and provided legal protection.

Communities of moist meadows from the alliance $\mathrm{Mo}$ linion caeruleae have been widely distributed in Kraków and reported from e.g. Kostrze, Skotniki, Sidzina, Kobierzyn, and Kliny (Denisiuk 1987; Dubiel 1991, 1995, 1996). Currently, the moist meadows are found only in the area of Kostrze, Tyniec, Sidzina, Lusina, Kosocice, Bieżanów, Nowa Huta, and Kościelniki. A vast majority of these meadows are now abandoned areas undergoing spontaneous succession. In recent years, the research conducted in these communities has been focused on the biology of rare species populations, e.g. Dactylorhiza majalis, Dianthus superbus, Iris sibirica, Trollius europaeus, Veronica longi- folia, Gentiana pneumonanthe, and Gladiolus imbricatus (Bochniak 2011; Kostrakiewicz 2007, 2009; Kostrakiewicz-Gierałt 2013b; 2014b; 2014c, 2014d), and seedling recruitment (Kostrakiewicz-Gierałt 2013a, 2014a).

\section{Materials and methods}

The field study was carried out in 2015. Using the Braun-Blanquet method, 35 relevés were taken in homogeneous stands representing plant communities from the alliance Molinion caeruleae. Seventeen relevés taken with the same method in 1986-1991 (Dubiel 1996) served as a reference material. The current observations were carried out in the same vegetation stands as 25 years ago, although not in the same research plots. The relevés were taken in three localities, which are shown in the figure (Fig. 1). The geographical coordinates of the centre of the stand in the WGS 84 system were specified for each locality using a GPS Garmin GPSmap 62s receiver.

The entire phytosociological material was combined in one set and subjected to numerical hierarchical classification twice: based on the presence/absence $(0,1$ binary scale) and abundance ( $\mathrm{r}$ replaced with $0.1,+$ replaced with 0.5 ) of species (Dzwonko 2007). Dissimilarity between the relevés was calculated using Jaccard's coefficient (quali- 
tative data) and its counterpart - Ružička's coefficient (quantitative data). Grouping was based on the weighted pair group method with averaging (WPGMA). The classification was carried out using a SYN-TAX 2000 package (Podani 2001). The diagram presenting the grouping of the phytosociological relevés was derived by comparison of two resulting dendrograms following the full compliance rule (Dzwonko \& Loster 1990). Thus, groups of relevés that were similar in terms of species occurrence and abundance were distinguished. Determination of the syntaxonomic position of the species was based on the studies by Dubiel (1996), Zarzycki (1958), and Matuszkiewicz (2008). The nomenclature of vascular plants and mosses followed those proposed by Mirek et al. (2002) and Ochyra et al. (2003), respectively. Protected species were enlisted based on the Regulation of the Minister of the Environment (Regulation 2014).

\section{Results}

\subsection{Current state}

The analysed meadow stands comprise 129 vascular plant species and 6 moss species. From 17 to 50 species (on average 36) were noted (Table 1) in the relevés. Characteristic species for the alliance Molinion caeruleae exhibited great abundance and high constancy degrees. Molinia caerulea, Galium boreale, and Sanguisorba officinalis were dominant in a majority of the stands.

Sixteen species characteristic for the alliance Molinion caeruleae were noted. High constancy degrees (III-V) were found for Molinia caerulea, Galium boreale, Serratula tinctoria, Succisa pratensis, Carex tomentosa, and Selinum carvifolia. The greatest abundance was reported for Molinia caerulea, Galium boreale, and Betonica officinalis, which formed large clusters. Iris sibirica and Inula salicina were present in a few stands, but they were characterised by high abundance and sociability. Other species exhibited a lower abundance or occurred sporadically. Noteworthy is the presence of 15 specimens of Ophioglossum vulgatum in a stand representing an advanced stage of Molinia meadow succession. Seven species accompanying the alliance Molinion were found, with Potentilla erecta and Briza media occurring most abundantly. This group comprised Salix rosmarinifolia, which formed larger clusters in several stands.

The alliance Calthion palustris was represented by 8 species. Constancy degree IV was achieved by Polygonum bistorta and Crisium rivulare, which had a significant share in the community structure in a majority of stands. The occurrence of other species was rather sporadic.

The presence of four species characteristic for the alliance Filipendulion ulmariae was reported. Among these,
Lythrum salicaria, Geranium palustre, and Filipendula ulmaria exhibited high constancy and formed larger clusters in some stands.

The order Molinietalia caeruleae was represented by 10 species. High constancy degrees were reported for Sanguisorba officinalis, Deschampsia caespitosa, Lysimachia vulgaris, and Lotus uliginosus. The greatest significance in determination of the community structure was ascribed to Sanguisorba officinalis and Deschampsia caespitosa, which exhibited high abundance in a majority of the stands and represented co-dominant species.

There were 27 species characteristic for the class $\mathrm{Mo}$ linio-Arrhenatheretea; however, a vast majority occurred sporadically and with low abundance degrees.

In the analysed stands, 8 species from the class Phragmitetea were found. Phragmites australis (V) and Peucedanum palustre (III) were characterised by the greatest constancy. Localities with a higher moisture level were dominated by Phragmites australis.

The class Scheuchzerio-Caricetea nigrae was represented by 4 species only, i.e. Carex nigra, Epipactis palustris, Juncus articulatus and Eriophorum latifolium. In some stands, the abundance of Epipactis palustre was high, as there were 30-40 flowering individuals in some relevés.

Additionally, we noted 6 ruderal habitat species from the class Artemisietea vulgaris (e.g. Solidago canadensis, S. gigantea, Cirsium arvense, Tanacetum vulgare), which occurred in transformed or disturbed habitats in the vicinity of the analysed meadows.

45 species were classified to the group of other species. A majority of these had a marginal share in the community structure. Higher constancy degrees (IV-V) were only achieved by Galium verum, Filipendula vulgaris, and Equisetum arvense. This group comprised species associated with thermophilic communities (e.g. Galium verum, Filipendula vulgaris, Ranunculus polyanthemos, Campanula glomerata) encroaching from xerothermic grasslands and fresh meadows. Other species were represented by young tree and shrub specimens (e.g. Salix cinerea and S. pupruprea, Betula pendula, Malus domestica) and five moss species, with Plagiomnium elatum and Calliergonella cuspidata forming larger clusters.

The high natural values of the investigated area are confirmed by the presence of 10 protected species: Gladiolus imbricatus, Iris sibirica, Gentiana pneumonanthe, Dianthus superbus, Trollius europaeus, Ophioglossum vulgatum, Epipactis palustris, Dactylorhiza majalis, Dactylorhiza incarnata, and Platanthera bifolia. 


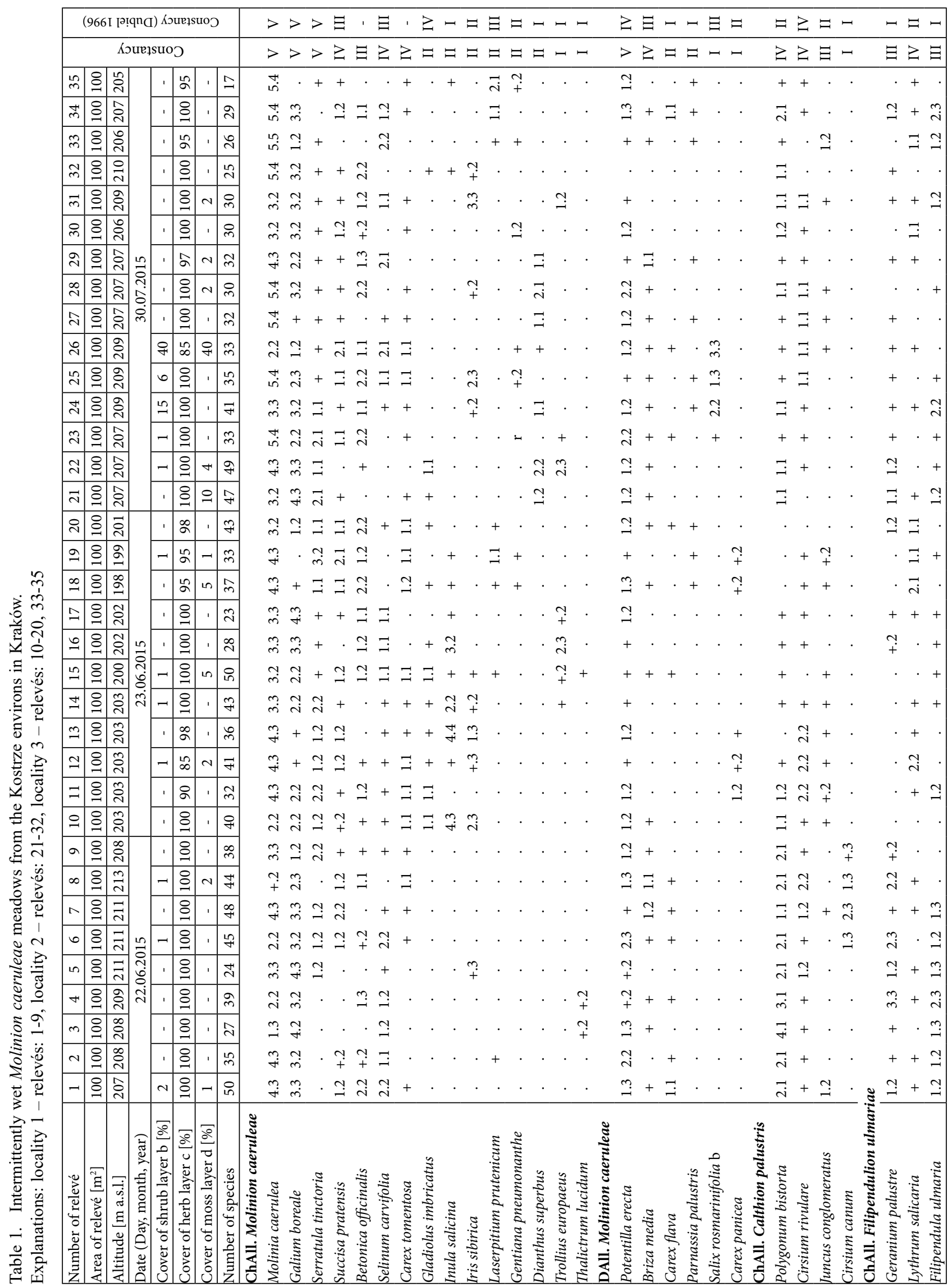




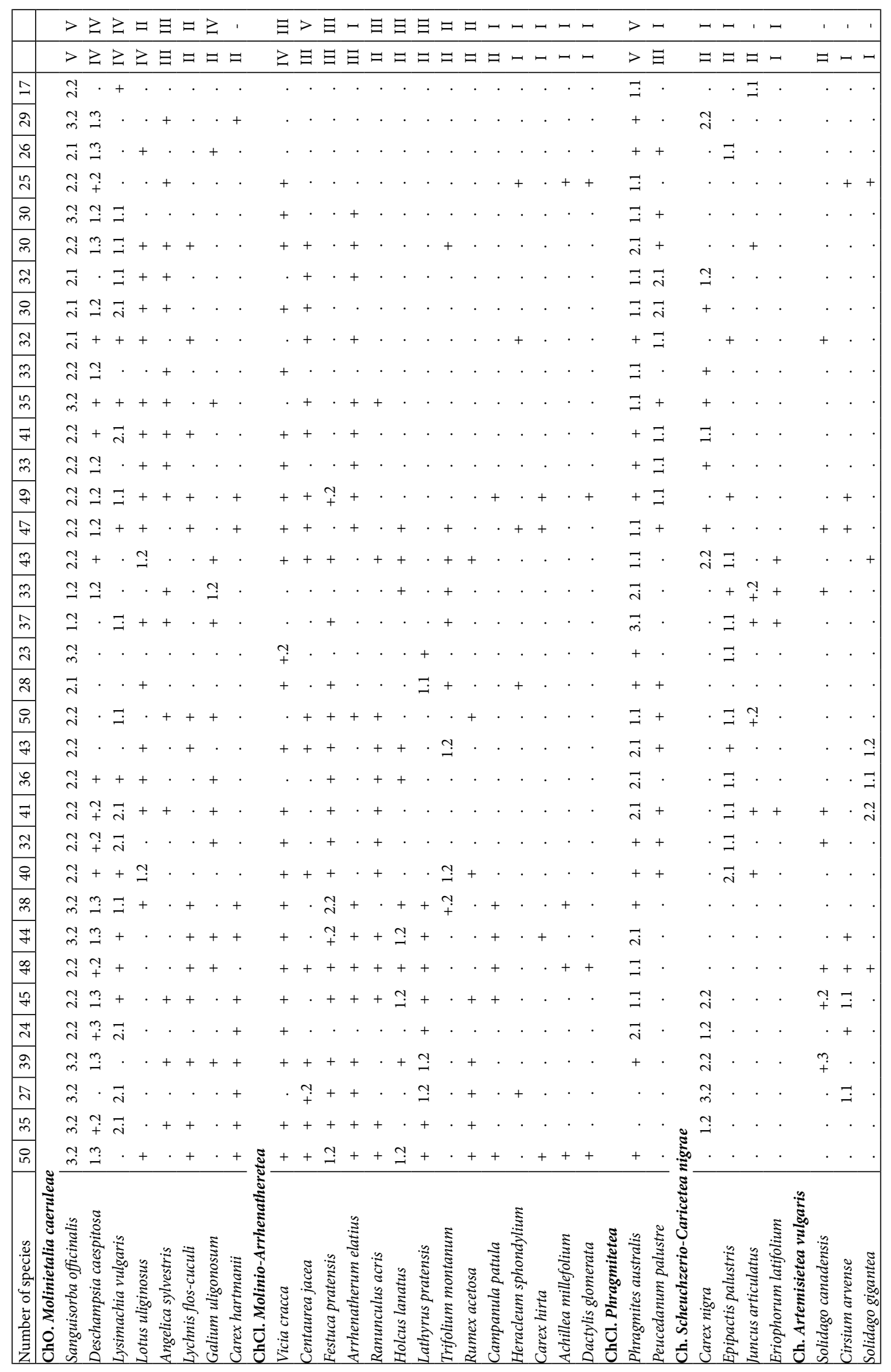




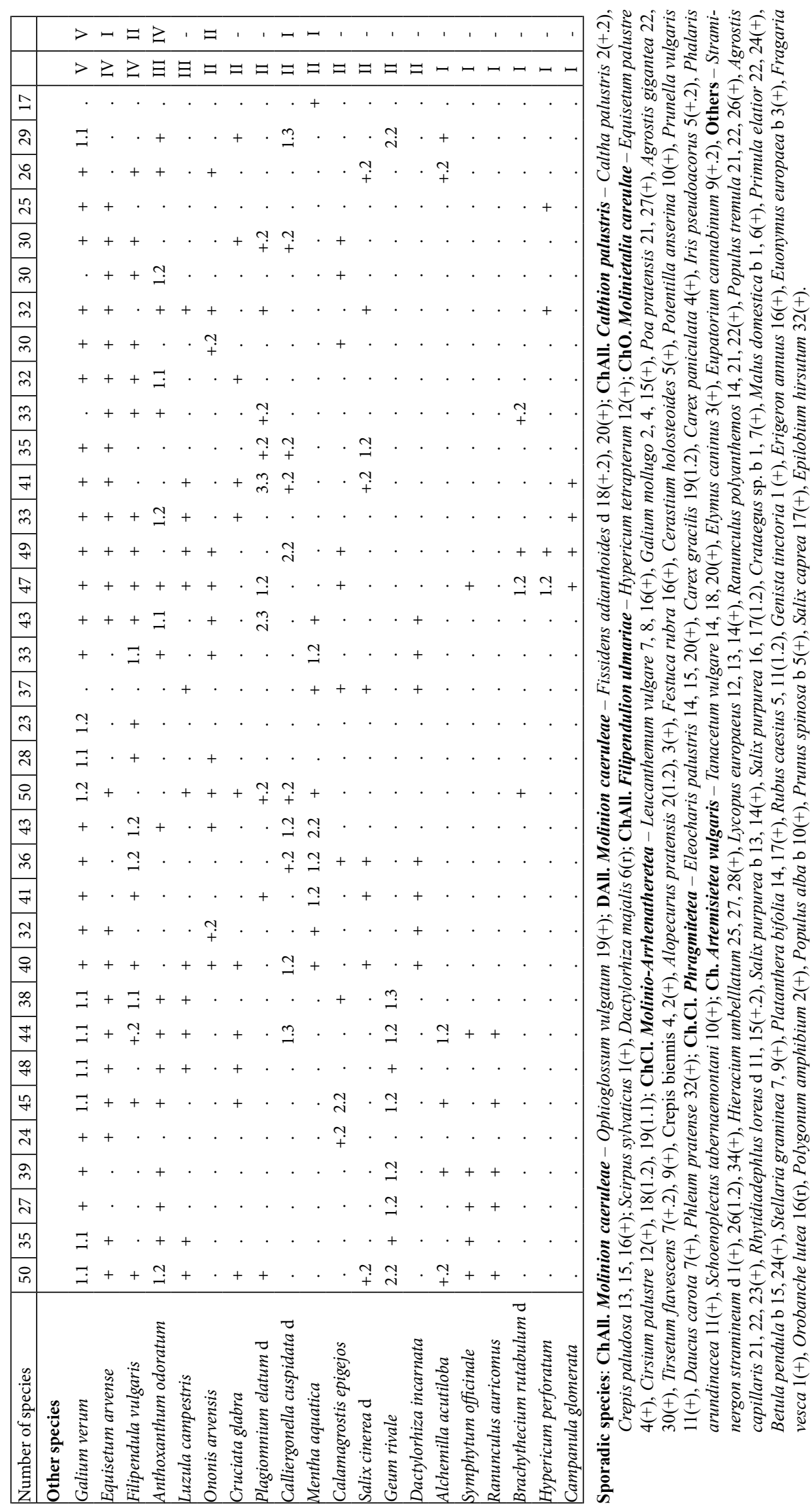




\subsection{Changes occurring over 25 years}

At present, the average number of species present in the purple moor-grass meadows in Kostrze is higher than 25 years ago (an increase from 28 to 36). The list of characteristic species has not changed substantially, and differences in the floristic composition are evident only for sporadic species. Three new species have been noted, i.e. Betonica officinalis, Carex tomentosa, and Ophioglossum vulgatum. The proportion of Gladiolus imbricatus and Laserpitium prutenicum has declined, while Succisa pratensis, Selinum carvifolia, Inula salicina, and Dianthus superbus have achieved a higher constancy degree.
The number of species from the alliance Calthion has not changed, but the abundance of Polygonum bistorta and Cirsium rivulare has increased.

We reported a considerable increase in the proportion of tall herb species from the alliance Filipendulion (Lythrum salicaria, Filipendula ulmaria, Geranium palustre), which had been characterised by very low occurrence in the previous investigation period. In turn, there were no major changes within the order Molinietalia and the class Molinio-Arrhenatheretea.

The number of Phragmitetea species has increased from 3 to 7. A high increase in abundance was noted in the case of Phragmites australis and Peucedanum palustre.

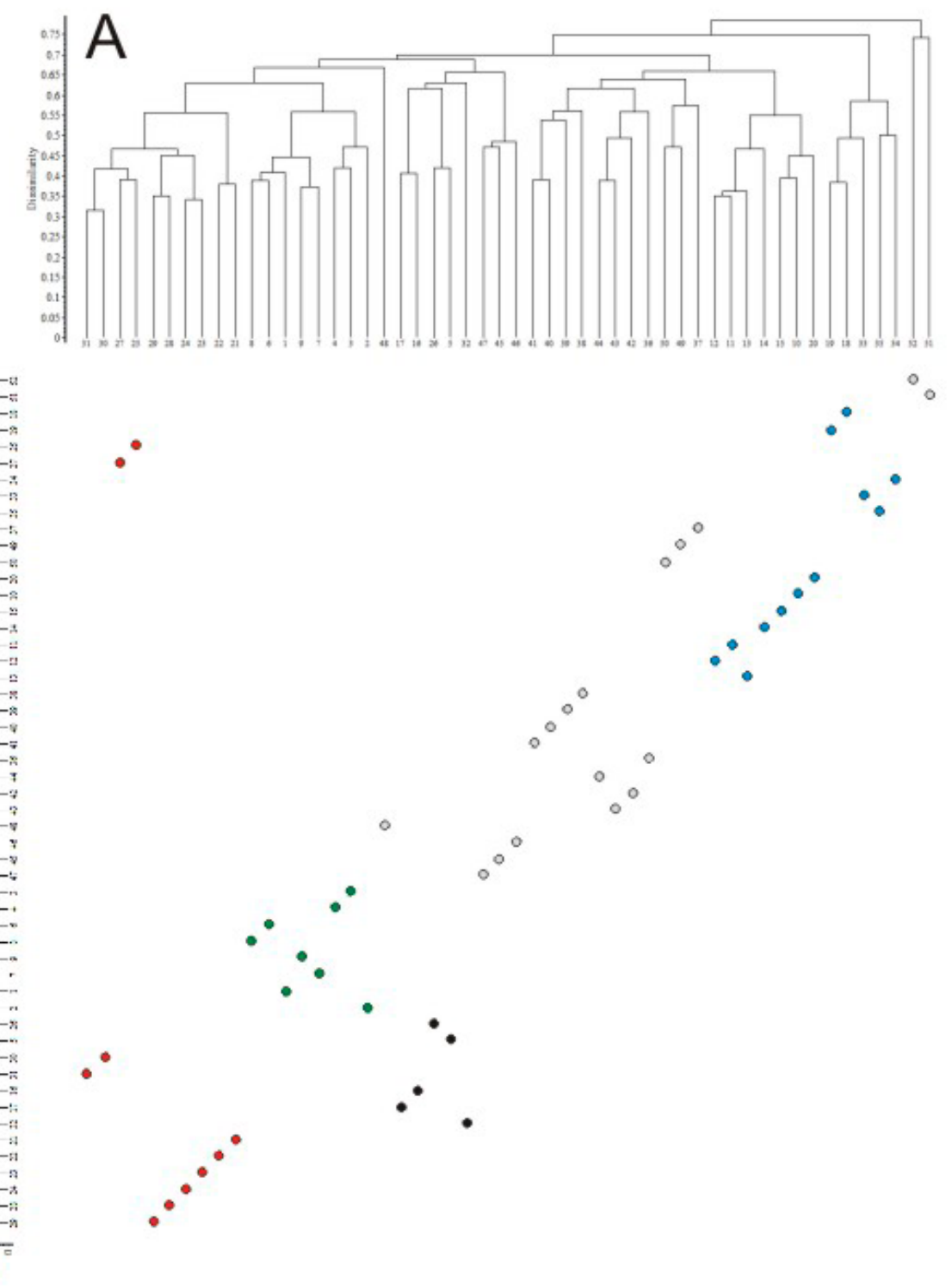

Figure 2. Classification and dispersion diagram of 52 relevés taken in the communities from the alliance Molinion. The dendrograms were created on the basis of: A - presence/absence of species (Jaccard' coefficient), B - species abundance (Ružička's coefficient). The numbers in the dendrograms correspond with the field numbers of relevés 
A number of new species from a group of sporadically occurring vegetation have appeared in the study area. Several relevés showed the presence of invasive species (Solidago gigantea and Solidago canadensis), which are characterised by remarkable expansion in the drier habitats adjacent to the Molinia meadows.

For comparison of the current and historical study results, a diagram presenting the diversity of the meadow vegetation in the analysed stands was prepared (Fig. 2). Five groups were distinguished and marked in different colours. The first group comprises archival stands (I - grey dots). The second group includes burnt-meadows in locality 3 (II - blue dots). They are characterised by a high proportion of Inula salicina and Laserpitium prutenicum, as well as occurrence of Epipactis palustris and Dactylorhiza incarnata orchids, which grow only in this stand. The third group (III - red dots) comprises relevés taken in an enclave surrounded by Phragmitetum australis in locality 2 . The stands are characterised by the highest species richness and a high proportion of species characteristic for Molinia meadows. Additionally, they exhibit the presence of Dianthus superbus and a higher share of Peucedanum palustre and Betonica officinalis. The next group of the relevés (IV - green dots) presents stands located along Skotnicka Street in locality 1 . They are clearly characterised by dominance of Molinia caerulea and Galium boreale and a low abundance of other species from the alliance Molinion. Furthermore, scrub species Deschampsia caespitosa and Filipendula ulmaria, as well as Polygonum bistorta and Geum rivale exhibit increased abundance. The last group of the relevés ( $\mathrm{V}$ - black dots) differs in its species composition from the other stands (locality 2). It comprises impoverished Molinia meadows with a species composition similar to that of scrub communities.

\section{Discussion and conclusions}

In Poland and Central Europe, purple moor-grass meadows are endangered, gradually disappearing landscape elements. For many years, their surface area has been decreasing due to replacement with arable land and undermowed as well as housing developments (Tumidajowicz \& Zubel 1978; Kępczyński \& Załuski 1991; Dubiel 1996; Ellenberg 1988; Kucharski 1999; Kołodziejek \& Michalska-Hejduk 2004; Suder 2008; Chytrý 2010; Hegedüšová \& Škodová 2014).

The major threats to moist meadows include changes in water relations, excessive fertilisation, and changes in land management, i.e. either intensification or complete abandonment of management (Ellenberg 1988; Kotańska 1993; Załuski 2007, 2011; Suder 2008; Michalska-Hejduk \& Kopeć 2012; Trąba \& Wolański 2012; Kulik 2014). Many authors report that abandonment is the primary cause of the disappearance of Molinia meadows. It results in accu- mulation of biomass leading to reduced species diversity, increased coverage of some perennials (e.g. Deschampsia caespitosa, Filipendula ulmaria), and spread of trees and shrubs. Consequently, disappearance of characteristic species, reduction of the surface area of typical communities and associations, and emergence of impoverished communities devoid of a majority of rare and Molinion-characteristic species can be observed (Bator 2005; Kompała-Bąba \& Bąba 2007; Suder 2008; Bochnak 2011; Trąba \& Wolański 2012).) Abandonment of meadows in periodically or excessively wet areas promotes development of scrub communities from the alliance Filipendulion (Ellenberg 1988; Załuski 2011). In this case, Filipendula ulmaria, which is an expansive species regarded as a long-term succession promoter, may become one of the dominant species (Trąba \& Wolański 2012). In turn, drainage of Molinia meadow habitats combined with abandonment of mowing initially leads to expansion of Molinia caerulea, which eliminates most therophytes, biennials, and low perennials. Consequently, drastic impoverishment of hygrophilous species phytocoenoses is observed. In excessively desiccated habitats, spread of synanthropic species, e.g. Urtica dioica, Cirsium arvense, Calamagrostis epigejos, and Potentilla anserina, as well as tall perennials, trees, and shrubs takes place (Bator 2005; Kompała-Bąba \& Bąba 2007; Trąba \& Wolański 2012).

In many regions of the country, the conservation status of Molinia meadows is inadequate. In the Central Sudetes, fragmentation and reduction in the surface area of meadows caused by development of tree and shrub undergrowth and expansion of Phragmites australis was reported (Somczyk 2013). In an analysis of trends in the changes in the vegetation cover of meadow communities in Wielkopolska, Grynia (1996) observed that deteriorating moisture conditions exerted the greatest impact. This leads to a decrease in the surface area of periodically wet meadows from the order Molinietalia or even to their disappearance. A further decline in the groundwater level results in transformation of purple moor-grass meadows into communities from the order Arrhenatheretalia. Similar processes take place in the Silesian Upland, where Molinietum caeruleae phytocoenoses are becoming impoverished, which is evidenced by absence of many characteristic species. Successional transformations caused by abandonment and lowered groundwater levels lead to a reduction of the number of hygrophilous species from the alliances Calthion and Molinion in favour of fresh meadow species (Kompała-Bąba \& Bąba 2007).

In the Wieliczka Foothills, investigations of transformations of meadow communities were conducted by Bator (2005). In a 40-year-scale, the author noted only eight characteristic species in the association Molinietum caeruleae, with Molinia caerulea and Betonica officinalis exhibiting higher constancy degrees. A majority of stands 
were abandoned. The author regarded the stands as a degraded form of Molinietum caeruleae. This was confirmed by the dominance of Molinia caerulea and the presence of expansive species: Filipendula ulmaria, Cirsium oleraceum, Phragmites australis, and Calamagrostis epigejos. The individual stands represented different stages of succession. Wet areas were clearly dominated by Filipendula ulmaria, moist areas by Cirsium oleraceum, and dry and insolated habitats by Calamagrostis epigejos. In turn, areas with a variable groundwater level were occupied by Phragmites australis. Expansion of $P$. australis in meadows characterised by secondary swamping was observed by Załuski (2011) in the Kujawy-Pomerania region. In the area of Kostrze, this grass colonises similar habitats.

Transformations of the vegetation cover of the Vistula River valley in Kraków were investigated by Dubiel (1995). The author found that most areas along the Vistula River had been built-up or otherwise transformed by man. The exceptions were small stands of scrubs, meadows, and fields mainly located in the western part of the city. Moist meadow stands have remained mainly in the depressions of the Vistula River valley, but they are currently abandoned. The process of spontaneous succession, to some extent impeded by spring grassland burning, takes place there.

The problem of disappearance and transformation of meadow communities in the Vistula River valley was analysed in detail by Tumidajowicz \& Zubel (1978) in the Czernichów environs. The area mapping from 1947 and 1972 was the basis for identification of the trends in the transformations occurring in two research periods. The authors found a distinct decline in the number of characteristic species (Gentiana pneumonanthe, Molinia caerulea, Galium boreale, Serratula tinctoria). A majority of stands of Molinietum caeruleae moist meadows had been transformed into meadows from the order Arrhenatheretalia and transitional communities between Molinion and Arrhenatheretalia. The surface area of the association Molinietum caeruleae decreased from 86 to $1 \%$, while the area of arable land increased due to ploughing of meadows.

In Kostrze, the abandonment of land use triggered succession towards scrub communities with a high proportion of Lythrum salicaria, Filipendula ulmaria, and Geranium palustre as well as spread of expansive grass species (Calamagrostis epigejos, Phragmites australis). In long-abandoned stands, young specimens of trees and shrubs have appeared (e.g. Salix cinerea, Populus tremula). The process of succession in the analysed meadows was reported previously. Seedlings and young specimens of Frangula alnus, Alnus glutinosa, Betula pendula, Populus tremula, and Salix sp. were noted at that time (Dubiel 1996; Bochnak 2011).

The process of overgrowth of some stands is impeded by grass burning, which should be regarded as a factor promoting conservation of endangered phytocoenoses (Dubiel
1996). However, grass burning itself is insufficient for sustenance of the characteristic combination of species (Ellenberg 1988). In this study, clear differences were noted in the species composition in stands that had been burnt in the previous year. The stands were characterised by the dominance of Molinia caerulea, great abundance of Inula salicina, absence of scrub species, and presence of orchids (Epipactis palustris and Dactylorhiza incarnata), which did not grow in unburnt stands (locality 3). Similar observations were reported by Dubiel (1996), who noted occurrence of tall perennials such as Galium boreale, Galium verum, Centaurea jacea, Lysimachia vulgaris, and Inula salicina in areas affected by burning. Dominance of Molinia caerulea in burnt Molinia meadows was also reported by Ellenberg (1988).

In recent years, the meadows in Kostrze have been the object of research conducted by Kostrakiewicz-Gierałt (2013a, 2014b), who investigated seedling recruitment in Molinion caeruleae stands representing various stages of secondary succession and dominated by different species. The author noted that the seedling recruitment process was inhibited by the layer of plant litter and mosses as well as tall vegetation. In turn, it was positively influenced by mowing and removal of dominant species, e.g. Molinia caerulea. The author concluded that rupture in the dense vegetation cover and litter may contribute to conservation of purple moor-grass meadows. Creation of various-size gaps seems to be particularly important for sustenance of species diversity, especially in the advanced stages of succession (Kostrakiewicz-Gierałt 2013a, 2014b).

Preservation of the species richness in Molinia meadows largely depends on management practices and maintenance of a proper water regime. Many authors report that regular mowing in late summer at least every second year combined with removal of biomass is an essential factor in prevention of succession (Ellenberg 1988; Kołodziejek \& Michalska-Hejduk 2004; Załuski 2007).

After a 20-year study period, no significant changes in the species composition were noted. In a majority of the stands, Molinia caerulea, Galium boreale, and Sanguisorba officinalis were the dominants species. The scrub and expansive species cover has increased as a result of abandonment. The meadows in Kostrze are still floristically rich communities with a high nature value evidenced by the presence of rare and protected species. However, fragmentation and reduction of many stands was noted. Sites with higher moisture content were occupied by rush communities with Phragmites australis and the desiccated habitats were colonised by expansive species such as Calamagrostis epigejos, Solidago gigantea, and S. canadensis. These species disturb the mosaic of microhabitats indispensable for co-occurrence of many different species, which leads to a decline in floristic richness and gradual overgrowth of the stands (Bochnak 2011). 
The major threats to the analysed phytocoenoses include natural biocoenotic processes, which are related to abandonment of traditional management practices. The study area is decreasing year by year due to the expanding infrastructure, and other meadow stands are occupied by housing developments, industry, and roads. The problem of changing the category of land use has been repeatedly addressed in previous studies (Dubiel 1991, 1995, 1996; Dubiel \& Szwagrzyk 2008; Bochnak 2011). As suggested by Dubiel (1995), conservation of at least some fragments of the remaining stands of meadow communities will only be effective under appropriate forms of protection.

\section{References}

Barabasz B., 1997, Zmiany roślinności łąk w północnej części Puszczy Niepołomickiej w ciągu 20 lat [Changes in the meadows of the northern part of the Niepołomice Forest during twenty years], Studia Naturae 43: 1-99.

Bator I., 2005, Stan obecny i przemiany zbiorowisk łąkowych okolic Mogilan (Pogórze Wielickie) w okresie 40 lat [Present state and changes of meadow communities in the environs of Mogilany (Wieliczka Foothills) during forty years], Fragmenta Floristica et Geobotanica Polonica, Suplementum 7: 3-97.

Bochnak D., 2011, Stan populacji rzadkich gatunków roślin naczyniowych w zespole Molinietum caeruleae w okolicach Tyńca i Sidziny [Populations status of rare vascular plants in Molinietum caeruleae association in vicinity of Tyniec and Sidzina (S Poland)], Chrońmy Przyrodę Ojczystą 67(3): 210-217.

Brzeg A. \& Wojterska M., 2001, Zespoły roślinne Wilkopolski, ich stan poznania i zagrożenie [Plant communities in Great Poland, their recognition state and status of threat], [in]: M. Wojterska (ed.), Szata roślinna Wielkopolski i Pojezierza Południowo-Pomorskiego [Vegetation of Great Poland and South-Pomeranian Lakeland], Wyd. Naukowe Bogucki, Poznań: 39-110.

Chytrý M., (ed.), 2010, Vegetace České Republiky. 1. Travinná a keřičková vegetace [Vegetation of the Czech Republic, 1. Grassland and Heathland Vegetation], Academia, Praha.

Denisiuk Z., 1987, O ochronę nadwiślańskich łąk w Krakowie [Let us safeguard the riverside along the Vistula in Cracow], Chrońmy Przyrodę Ojczystą 43(2): 22-31.

Dubiel E., 1991, Mapa roślinności rzeczywistej miasta Krakowa [Map of actual vegetation of the city of Cracow], Zeszyty Naukowe UJ, Prace Botaniczne 22: 121-133.

Dubiel E., 1995, Kierunki antropogenicznych przemian szaty roślinnej doliny Wisły w Krakowie [Trends in anthropogenic changes in the Vistula valley vegetation in Cracow], Folia Geographica Series Geographico-Physica 26/27: 139-148.
Dubiel E., 1996, Łąki Krakowa, Cz. I. Klasa Molinio-Arrhenatheretea [Meadows of Cracow Part. I. MolinioArrhenatheretea class], Studia Ośrodka Dokumentacji Fizjograficznej 24: 145-171.

Dubiel E. \& Szwagrzyk J. (eds.), 2008, Atlas roślinności rzeczywistej Krakowa [Atlas of actual vegetation of the city of Cracow], Urząd Miasta Krakowa, Kraków.

Dyrektywa 1992, Dyrektywa Rady 92/43/EWG z dnia 21 maja 1992 roku w sprawie ochrony siedlisk naturalnych oraz dzikiej fauny i flory [Council Directive 92/43/EEC of 21 May 1992 on the conservation of natural habitats and of wild fauna and flora], http://eur-lex.europa.eu/ eli/dir/1992/43/08

Dzwonko Z., 2007, Przewodnik do badań fitosocjologicznych [Guidebook to phytosociological studies], Vademecum Geobotanicum 2, Sorus Poznań, Inst. Bot. UJ Kraków.

Dzwonko Z. \& Loster S., 1990, Vegetation differentiation and secondary succession on a limestone hill in southern Poland, Journal of Vegetation Science 1: 615-622.

Ellenberg H., 1988, Vegetation Ecology of Central Europe, Cambrige University Press, Cambridge-New YorkNew Rochelle-Melbourne-Sydney.

Grynia M., 1996, Kierunki zmian szaty roślinnej zbiorowisk łąkowych w Wielkopolsce [Direction of floristic changes of meadow communities in Wielkopolska Region], Roczniki Akademii Rolniczej w Poznaniu 272: 15-27.

Havlová M., 2006, Syntaxonomical revision of the Molinion meadows in the Czech Republic, Preslia 78(1): 87-101.

Hegedüšová K. \& Škodová I., (eds.), 2014, Vegetácia Slovenska. Rastlinné spoločenstvá Slovenska, 5. Travinnobylinná vegetácia [Vegetacion of Slovakia. Plant communities of Slovakia. 5. Grassland vegetation], Slovak Akademy of Sciences, Bratislava.

Kącki Z. \& Michalska-Hejduk D., 2010, Assessment of biodiversity of Molinia meadows in Kampinoski National Parks based on biocoenotic indicators, Polish Journal of Environmental Studies 19(2): 351-362.

Kącki Z., 2007, Comprehensive syntaxonomy of Molinion meadows in southwestern Poland, Acta Botanica Silesiaca, Monographiae 2: 1-136.

Kącki Z., 2012, Variability and long-term changes in the species composition of Molinia meadows in Poland: a case study using a large data set from the Polish Vegetation Database, Acta Botanica Silesiaca, Monographiae 7: 1-144.

Kępczyński K. \& Załuski T., 1991, Zróżnicowanie roślinności łąk trzęślicowych $\mathrm{w}$ dolnym odcinku doliny Rukutówki [Diversity of Molinia meadow vegetation in the lower section of the Rukutówka River valley], Acta Universitatis Nicolai Copernici, Biologia 36(74): 41-55. 
Kołodziejek J. \& Michalska-Hejduk D., 2004, Charakterystyka geobotaniczna łąk trzęślicowych Molinietum caeruleae na polanach śródleśnych północnej części województwa śląskiego [Geobotanic characteristics of the purple moor-grass meadow community Molinietum caeruleae on the clearings in the northern part of the Silesia voivodeship], Fragmenta Floristica et Geobotanica Polonica 11: 141-155.

Kompała-Bąba A. \& Bąba W., 2007, Przemiany składu florystycznego zbiorowisk łąkowych Kotliny Dąbrowskiej (Wyżyna Śląska) jako wynik zaprzestania tradycyjnych form użytkowania i degradacji środowiska [Changes in the floristic composition of the meadow plant communities of the Dąbrowska Basin (Silesian Upland) as a result of cessation of the traditional management practices and environment degradation], Acta Botanica Warmiae et Masuriae 4: 173-186.

Kondracki J., 2011, Geografia regionalna Polski [Regional geography of Poland], Wyd. Nauk. PWN, Warszawa.

Kornaś J. \& Medwecka-Kornaś A., 1974, Szata roślinna Krakowa [The vegetation of Cracow], Folia Geographica Series Geographico-Physica 8: 153-169.

Kostrakiewicz K., 2007, The effect of dominant species on numbers and age structure of Iris sibirica L. population on blue moor-grass meadow in southern Poland, Acta Societatis Botanicorum Poloniae 76(2): 165-173.

Kostrakiewicz K., 2009, The influence of shadow created by adjacent plants on phenotypic plasticity of endangered species Trollius europaeus L. (Ranunculaceae), Polish Journal of Ecology 57(4): 625-634.

Kostrakiewicz-Gierałt K., 2013a. The impact of disturbance gradient on recruitment of clonal plant species in in Molinietum caeruleae meadows, Polish Journal of Ecology 61 (3): 519-533.

Kostrakiewicz-Gierałt K., 2013b, The effect of vegetation character on abundance and structure of subpopulations of rare herb species Gentiana pneumonanthe L., Polish Journal of Ecology 61(1): 35-43.

Kostrakiewicz-Gierałt K., 2014a, Are Deschampsia caespitosa (L.) Beauv. Tussocks safe sites for seedling recruitment in the succession of wet meadows?, Polish Journal of Ecology 62(4): 707-721.

Kostrakiewicz-Gierałt K., 2014b, The effects of successional stage and size of gaps on recruitment of clonal plants in overgrowing Molinietum caeruleae meadows, Acta Agrobotanica 67 (4): 87-98.

Kostrakiewicz-Gierałt K., 2014c, The life-history traits and seedling recruitment of Dianthus superbus L. in different stages of meadow overgrowing, Acta Agrobotanica 67 (2): 23-30

Kostrakiewicz-Gierałt K., 2014d, The variability of selected features of Gladiolus imbricatus L. in relation to successive stages of meadow communities following the mowing cessation, Polish Journal of Ecology 62(2): 307-321.

Kotańska M., 1993, Response of wet meadows of the Calthion alliance to variations of weather and management practices - a thirteen-year study of permanent plots, Studia Naturae 40: 1-47.

Kucharski L., 1999, Szata roślinna łąk Polski Środkowej i jej zmiany w XX stuleciu [The plant cover of Central Poland meadows and its changes in the $20^{\text {th }}$ century], Wyd. Uniwersytetu Łódzkiego, Łódź.

Kulik M., 2013, Ocena szaty roślinnej wybranych łąk trzęślicowych w Poleskim Parku Narodowym i poza jego obszarem [Evaluation of vegetation of selected Molinia meadows in Polesie National Park and outside its area], Łąkarstwo w Polsce 16: 39-54.

Kulik M., 2014, Changes of biodiversity and species composition of Molinia meadow depending on use method, Polish Journal of Environmental Studies 23(3): 773782.

Matuszkiewicz W., 2008, Przewodnik do oznaczania zbiorowisk roślinnych Polski [Guide to identification of plant communities of Poland], Wyd. Nauk. PWN, Warszawa.

Michalska-Hejduk D. \& Kopeć D., 2012, Dynamics of semi-natural vegetation with a focus of Molinion meadows after 50 years of strict protection, Polish Journal of Environmental Studies 21(6): 1731-1741.

Mirek Z., Piękoś-Mirkowa H., Zając A. \& Zając M., 2002, Flowering plants and pteridophytes of Poland a checklist [Krytyczna lista roślin naczyniowych Polski], W. Szafer Institute of Botany, Polish Academy of Sciences, Kraków.

Ochyra R., Żarnowiec J. \& Bednarek-Ochyra H., 2003, Census catalogue of Polish Moses [Katalog mchów Polski], W. Szafer Institute of Botany, Polish Academy of Sciences, Kraków.

Podani J., 2001, SYN-TAX 2000. Computer Programs for Data Analysis in Ecology and Systematics, Scientia Publishing, Budapest.

Pott R., 1995, Die Pflanzengesellschaften Deutschlands, Verlag Eugen Ulmer, Stuttgart.

Řezníčková M., 2007, Variability of the Molinion meadows in Slovakia, Biologia, Bratislava, Section Botany 62(6): 675-683.

Rozporządzenie Ministra Środowiska z dnia 9 października 2014 w sprawie ochrony gatunkowej roślin (Dz.U. 2014 poz. 1409) [Regulation of the Minister of Environment of 9 October 2014 on the plant species protection], Warszawa.

Somczyk M., 2013, Zróżnicowanie i zagrożenia łąk trzęślicowych ze związku Molinion w południowo-wschodniej części Sudetów Środkowych [Variability and conservation status of Molinia meadows in south-eastern 
part of the Central Sudetes Mts.], Przyroda Sudetów 16: 19-34.

Suder A., 2008, Purple-moor grass meadows (alliance $\mathrm{Mo}$ linion caeruleae Koch 1926) in the eastern part of Silesia Upland: phytosociological diversity and aspects of protection, Nature Conservation 65(8): 63-77.

Trąba C. \& Wolański P., 2012, Zróżnicowanie florystyczne zbiorowisk łąkowych ze związków Molinion, Cnidion dubii i Filipendulion w Polsce - zagrożenia i ochrona [Floristic diversity of meadows communities representing Molinion, Cnidion dubii and Filipendulion Alliance in Poland - threats and protection], Inżynieria Ekologiczna 29: 224-235.

Tumidajowicz D. \& Zubel E., 1978, Zanikanie i przemiany łąk trzęślicowych (Molinion caeruelae) w dolinie Wisły koło Czernichowa (Polska południowa) [The disappearance and changes of wet meadows (Molin- ion caeruelae) in the valley of the Vistula river near Czernichów (Southern Poland)], Fragmenta Floristica et Geobotanica 24(4): 643-650.

Załuski T., 2007, Zagrożenia i ochrona zespołów trawiastych [Threat and protection of grass communities], [in]: L. Frey (ed.), Księga polskich traw [The Book of Polish Grasses], Instytut Botaniki im. W. Szafera, Polska Akademia Nauk, Kraków: 283-316.

Załuski T., 2011, Vegetation transformations of $\mathrm{Ku}-$ jawy-Pomerania region in the last twenty years period, Acta Universitatis Lodziensis, Folia Biologica et Oecologica 7: 75-98.

Zarzycki K., 1958, Wilgotne łąki w okolicach Czernichowa $\mathrm{i}$ potrzeba ich ochrony [Humid meadows in the environs of Czernichow near Cracow deserving protection], Ochrona Przyrody 25: 49-68. 